\author{
Vyacheslav Zhyznevskiy, Volodymyr Gumenetskiy, O lena Shyshchak \\ and Yevhen Fedevych
}

\title{
THE USE OF ISOBUTYL ALCOHOL FOR METHACRYLATE SYNTHESIS
}

\author{
Lviv Polytechnic National University \\ 12, Bandery str., 790013 Lviv, Ukraine \\ Received: February 20, 2011 / Revised: February 28, 2011 / Accepted: M ay 31, 2011 \\ (C) Zhyznevskiy V., Gumenetskiy V., Shyshchak O., Fedevych Y., 2011
}

\begin{abstract}
Methyl methacrylates synthesis via oxidative conversion of isobutyl alcohol has been investigated in accordance with different schemes. The possibility of its use as an alternative raw material instead of isobutylene and tert-butyl alcohol has been established. Using the scheme isobutyl alcohol $\rightarrow$ methacrylonitrile $\rightarrow$ methyl methacrylate the product with ultimate yield of $64.8 \%$ has been obtained. Taking into consideration the recirculation of unreacted methacrolein the yield is $81.9 \%$. This scheme may be recommended for industrial application.
\end{abstract}

Keywords: oxidation, oxidative amonolysis, catalyst, methacrylonitrile, methyl methacrylate.

\section{Introduction}

Production of methacrylate monomers and polymeric materials on their basis is among the most important branches of chemical industry of any industrially advanced country. There is a tendency to increase their production capacity, however the lack of raw materials and accompanying ecological problems hinder this process.

The existing acetone cyanohydrine method $(\mathrm{ACH})$ of methyl methacrylate (MMA) synthesis uses extremely poisonous prussic acid ( $\mathrm{HCN})$. Moreover, using the existing technology six tons of waste products are formed from one ton of MMA. Ammonium sulphate is the main waste product, which is difficult to utilize.

The best method of MMA production is two-staged process of isobutylene (IB) or tert-butyl alcohol (TBA) oxidation to methacrolein (MA) and then to methacrylic acid (MAA). The first stage is sufficiently effective - MA yield is $85 \%$, IB conversion is $98 \%$, selectivity by MA is $86.7 \%$ [1]. In the case of TBA oxidation its conversion is $100 \%$, IB conversion is $99 \%$, selectivity by MA is $89.5 \%$ (calculated for IB), MA yield is $88.6 \%$ [2]. However, the second stage - MA oxidation to MAA - is insufficiently selective. MAA yield of the both stages is $72 \%$.

It is known that methyl methacrylates are valuable monomers of chemical industry. Polymethyl methacrylate
(PMMA) is a hard amorphous material characterized by transmittance, atmospheric stability, and good physicochemical and electroisolated properties. It is frost-resistant (till $213 \mathrm{~K}$ ) and thermostable at the same time. Under normal conditions it is stable to acids, alkali, light, and oxygen actions. At the heating to 378-383 K PMMA softens, turns into highly plastic state and is easily formed. Therefore, it is widely used for the production of optical and chemical glass, glues, optical instruments, varnishand-paint materials, etc. Apparently the methacrylate production capacity increases every year [3]. At the same time the deficit of the raw material (IB) is observed because the great amount of IB is used for the production of high-octane branched $\mathrm{C}_{8}$ hydrocarbons via the interaction between IB and butenes. Thus the search for alternative raw material instead of IB and TBA is an urgent problem. To our mind, such raw material may be isobutyl alcohol (IBA), which is obtained during alcohols oxysynthesis and which is a component of so-called "fusel oil" during ethanol production via fermentation of starch or sugar raw materials (molasses, sugar beet, etc.)

\section{Experimental}

The process in which IBA is used as raw material for MMA synthesis may proceed by different schemes.

According to Scheme (1) IBA is oxidized to isobutyric aldehyde (IBAld) and then to isobutyric acid (IBAc), which may be converted to MAA using oxidative dehydration. MMA is obtained by MAA esterification with methanol. It is known [3] that IBAc oxidative dehydration is a low-selective process $(\sim 50 \%)$. Methylisobutyrate (MIB) oxidative dehydration to MMA has higher selectivity; therefore we consider this conversion scheme. Moreover, MMA may be obtained by Scheme (2). IBA is oxidized to MA, then to MAA, which is converted into MMA using esterification with methanol. In accordance with Scheme (4) oxidative amonolysis is used to convert IBA into methacrylonitrile (MAN). MAN methanolysis in the presence of sulphate acid and methanol allows to obtain MMA. 


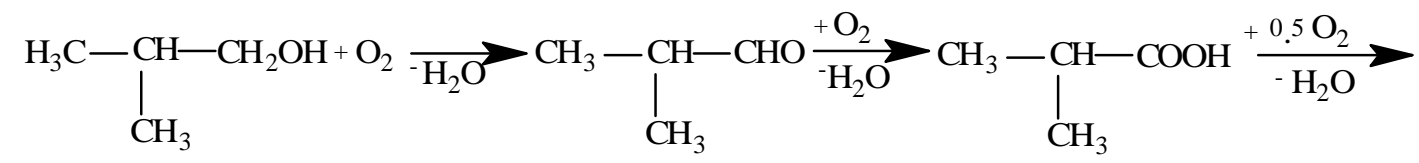

IBA

IBAId

IBAc

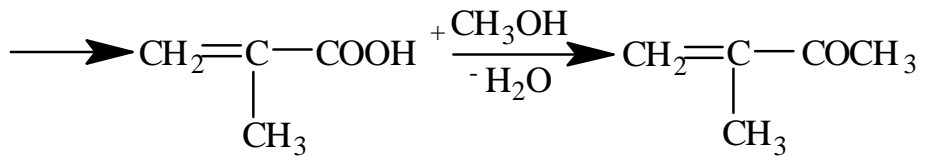

MAA

MMA

Scheme 1

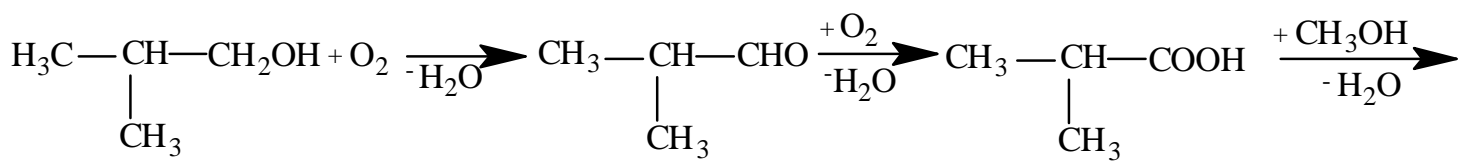

IBA

IBAld

IBAc

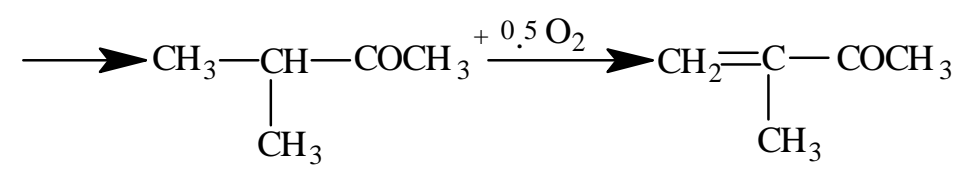

MIB

MMA

Scheme 2

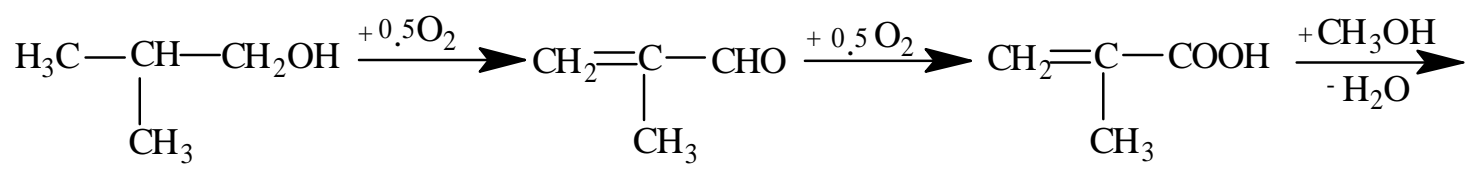

IBA

MA

MAA<smiles>CCC=C(C)C(C)=O</smiles>

MMA

Scheme 3

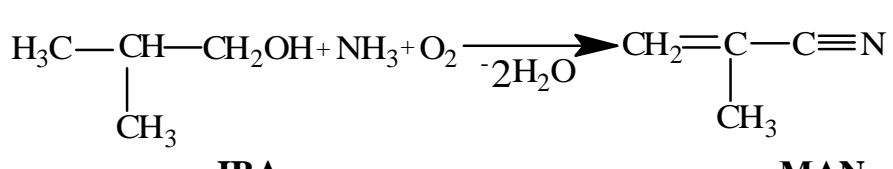

IBA

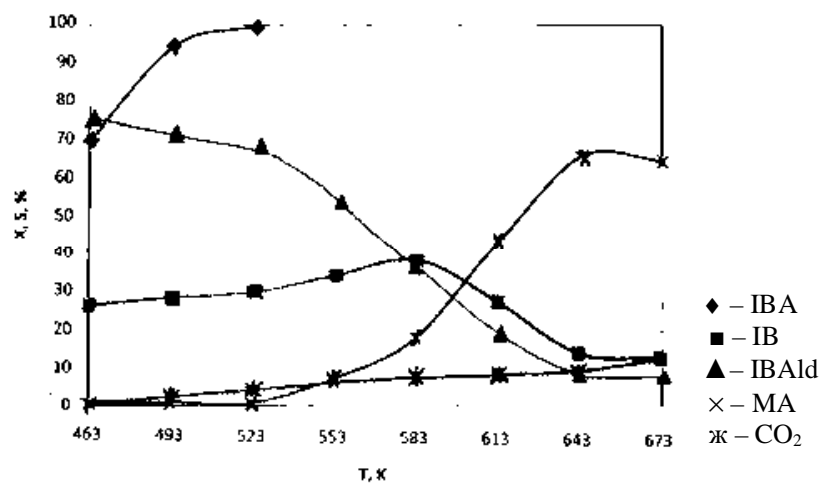

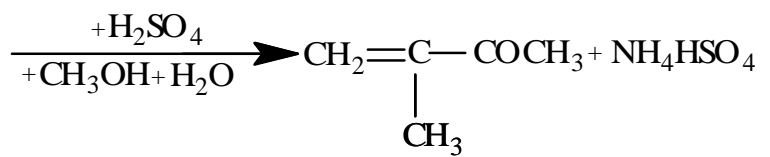

MMA

Scheme 4
Fig. 1. Dependence of IBA oxidation products selectivity upon the temperature at $\tau=1.2 \mathrm{~s}$. Flow reactor with stationary catalyst Fe:Te:Mo-O $\mathrm{x}(1: 0.85: 1)$ and impulse feed of reaction mixture (air + $4 \mathrm{~mol} \% \mathrm{IBA}$ ). 
For the first stage of Scheme (1) we used Fe:Te:Mo-O ${ }_{x}$ (1:0.85:1) catalyst (Cat) developed by V. Zhyznevskiy [5] for the oxidation of low-molecular olefins with high yield of unsaturated aldehydes. Experimental results are represented in Fig. 1.

One can see that Cat is effective in the mentioned reaction. The complete IBA conversion is achieved at the contact time $(\tau)$ of $1.2 \mathrm{~s}$ and the temperature of $523 \mathrm{~K}$. Under such conditions the reaction products are: IBAld (the main product), IB, MA (traces), and $\mathrm{CO}_{2}$.

Thus, the process optimum conditions are: $T=523 \mathrm{~K}, \tau=1.2 \mathrm{~s}$, and IBA concentration of $4 \mathrm{~mol} \%$. Under such conditions IBAld yield is $97.1 \%$.

\section{Results and Discussion}

\subsection{Kinetics of IBA Oxidation to MA}

To calculate the process it is necessary to know its kinetic regularities. Kinetics of IBA oxidation to MA was studied using micro-chromatographic method. The complete-mixing reactor with vibro-liquefied catalyst had the pulse feed of the reaction mixture [6] in the reaction kinetic area determined by Cat grains grinding and changing the flow linear rate at the constant contact time. It has been established that using Cat grains size of $1.5-2 \mathrm{~mm}$ at reactor shaking frequency of $50 \mathrm{~Hz}$ and flow rate $V_{\text {flow }} \geq 0.35 \mathrm{~cm} / \mathrm{s}$ the reaction proceeds in the kinetic area. At the mentioned shaking frequency and small doses of reagents fed by one impulse $\left(12.5 \mathrm{~cm}^{3}\right)$ the concentration and temperature drops in Cat layer were absent. The variation interval of temperature and concentrations are represented in Table 1 . Since the experiments were carried out at great excess of $\mathrm{O}_{2}$ in the reaction mixture containing less than $2 \mathrm{~mol} \%$ of IBA, we changed only IBA concentration in the air. Constants were calculated accordingly to the pseudo-first order reaction by IBA. The experimental results are confirmed by the data represented in Fig. 2.

Table 1

Kinetic regularities of IBA oxidation

over Fe:Te:Mo-O $\mathrm{O}_{\mathbf{x}}(\mathbf{1 : 0 . 8 5 : 1 )}$ catalyst at $\tau=1.2 \mathrm{~s}$

\begin{tabular}{|c|c|c|c|c|c|c|c|c|c|c|c|c|c|c|}
\hline \multirow{2}{*}{$\begin{array}{l}T, \\
\mathrm{~K}\end{array}$} & \multirow{2}{*}{$\begin{array}{l}C_{I B A} \cdot 10^{4} \\
\mathrm{~mol} / \mathrm{dm}^{3}\end{array}$} & \multicolumn{4}{|c|}{$\begin{array}{l}\text { Concentration of the reaction } \\
\text { products } C_{i} \cdot 10^{5}, \mathrm{~mol} / \mathrm{dm}^{3}\end{array}$} & \multicolumn{5}{|c|}{$\begin{array}{l}\text { Rate of products obtaining, } \\
\qquad W p_{i} \cdot 10^{5}, \mathrm{~mol} / \mathrm{dm}^{3} \cdot \mathrm{s}\end{array}$} & \multicolumn{4}{|c|}{ Rate constants, $\mathrm{s}^{-1}$} \\
\hline & & AA & IBAld & MA & $\mathrm{CO}_{2}$ & AA & IBAld & MA & $\mathrm{CO}_{2}$ & $\Sigma W$ & $\mathrm{AA} \cdot 10^{3}$ & IBAld & MA & $\underset{0^{3}}{\mathrm{CO}_{2} \cdot 1}$ \\
\hline 423 & 2.15 & 0.06 & 2.4 & 3.6 & 0.06 & 0.05 & 1.88 & 2.81 & 0.05 & 4.78 & 2.11 & 0.09 & 0.13 & 2.18 \\
\hline 423 & 4.30 & 0.11 & 4.9 & 6.8 & 0.12 & 0.09 & 3.83 & 5.31 & 0.09 & 9.32 & 2.00 & 0.09 & 0.12 & 2.18 \\
\hline 423 & 6.50 & 0.16 & 6.8 & 10.1 & 0.19 & 0.13 & 5.31 & 7.89 & 0.15 & 13.48 & 1.92 & 0.08 & 0.12 & 2.28 \\
\hline 423 & 8.50 & 0.22 & 9.3 & 13.3 & 0.24 & 0.17 & 7.27 & 10.39 & 0.19 & 18.02 & 2.02 & 0.09 & 0.12 & 2.21 \\
\hline \multicolumn{11}{|c|}{$k_{a v}$} & 2.01 & 0.09 & 0.12 & 2.21 \\
\hline 453 & 2.15 & 0.096 & 3.8 & 5.0 & 0.07 & 0.08 & 2.97 & 3.91 & 0.05 & 7.00 & 3.49 & 0.14 & 0.18 & 2.54 \\
\hline 453 & 4.30 & 0.196 & 6.9 & 7.2 & 0.15 & 0.15 & 5.39 & 5.63 & 0.12 & 11.29 & 3.55 & 0.13 & 0.13 & 2.73 \\
\hline 453 & 6.50 & 0.32 & 11.6 & 14.7 & 0.20 & 0.25 & 9.06 & 11.48 & 0.16 & 20.95 & 3.85 & 0.14 & 0.18 & 2.40 \\
\hline 453 & 8.50 & 0.42 & 13.4 & 17.9 & 0.31 & 0.33 & 10.5 & 13.98 & 0.24 & 25.02 & 3.86 & 0.12 & 0.16 & 2.85 \\
\hline \multicolumn{11}{|c|}{$k_{a v}$} & 3.69 & 0.13 & 0.16 & 2.63 \\
\hline 483 & 2.15 & 0.17 & 6.1 & 6.9 & 0.08 & 0.13 & 4.77 & 5.39 & 0.06 & 10.35 & 6.18 & 0.22 & 0.25 & 2.91 \\
\hline 483 & 4.30 & 0.29 & 8.4 & 10.9 & 0.17 & 0.23 & 6.56 & 8.52 & 0.13 & 15.44 & 5.27 & 0.15 & 0.20 & 3.09 \\
\hline 483 & 6.50 & 0.40 & 15.0 & 19.2 & 0.24 & 0.31 & 11.7 & 15.00 & 0.19 & 27.22 & 4.81 & 0.18 & 0.23 & 2.88 \\
\hline 483 & 8.50 & 0.51 & 16.2 & 21.8 & 0.37 & 0.40 & 12.7 & 17.03 & 0.29 & 30.38 & 4.69 & 0.15 & 0.20 & 3.40 \\
\hline \multicolumn{11}{|c|}{$k_{a v}$} & 5.24 & 0.18 & 0.22 & 3.07 \\
\hline 513 & 2.15 & 0.29 & 10.6 & 9.2 & 0.10 & 0.23 & 8.28 & 7.19 & 0.08 & 15.77 & \multirow{4}{*}{$\begin{array}{c}10.510 .5 \\
12.1 \\
10.5 \\
\end{array}$} & 0.39 & 0.33 & 3.63 \\
\hline 513 & 4.30 & 0.58 & 16.1 & 18.9 & 0.20 & 0.45 & 12.6 & 14.77 & 0.16 & 27.95 & & 0.29 & 0.34 & 3.63 \\
\hline 513 & 6.50 & 1.01 & 23.6 & 30.5 & 0.33 & 0.79 & 18.4 & 23.83 & 0.26 & 43.31 & & 0.28 & 0.37 & 3.97 \\
\hline 513 & 8.50 & 1.14 & 29.0 & 36.5 & 0.42 & 0.89 & 22.7 & 28.52 & 0.33 & 52.39 & & 0.27 & 0.34 & 3.86 \\
\hline \multicolumn{11}{|c|}{$k_{a v}$} & 10.9 & 0.31 & 0.34 & 3.77 \\
\hline
\end{tabular}

Note: $C_{I B A}$ was calculated as $C_{a v}=\frac{C_{0}+C_{k}}{2}$. Since $X_{I B A}=100 \%$ then $C_{a v}=\frac{C_{0}}{2} ; \mathrm{AA}-$ acetaldehyde 


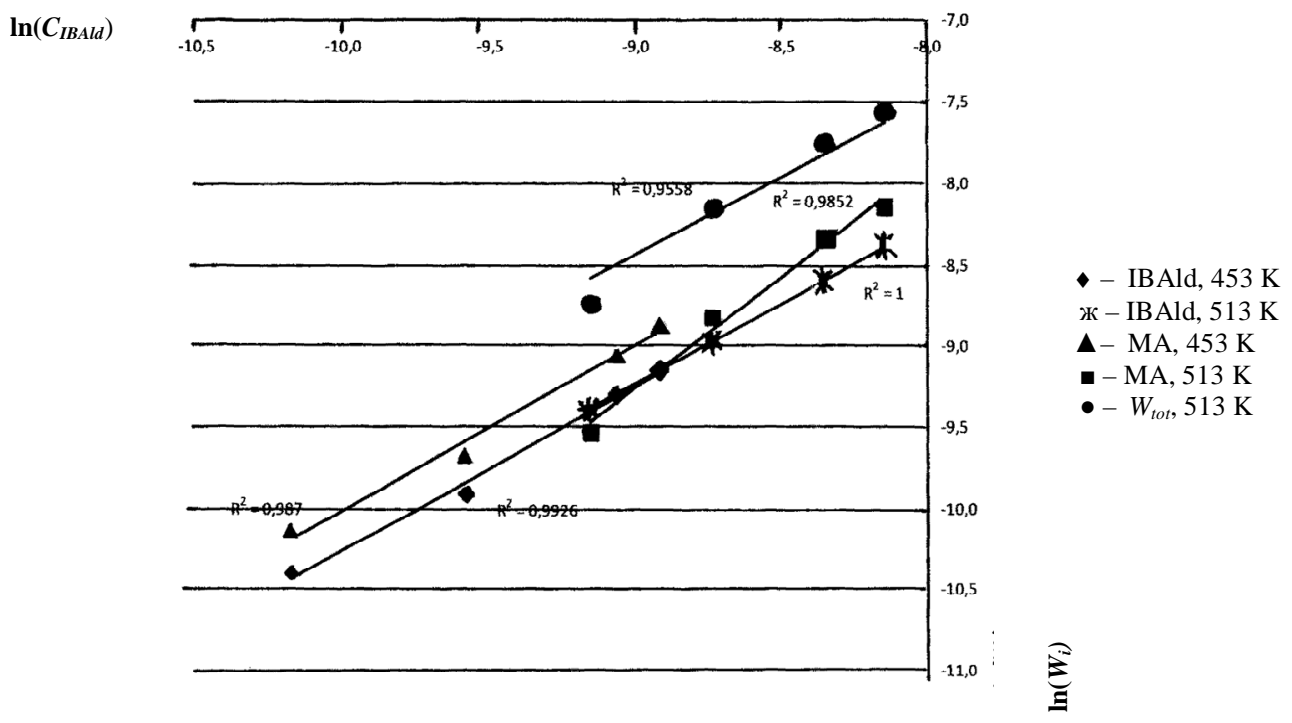

Fig. 2. $\ln \left(W_{i}\right)$ versus $\ln C_{I B A l d}$ at $\tau=1.2 \mathrm{~s}$

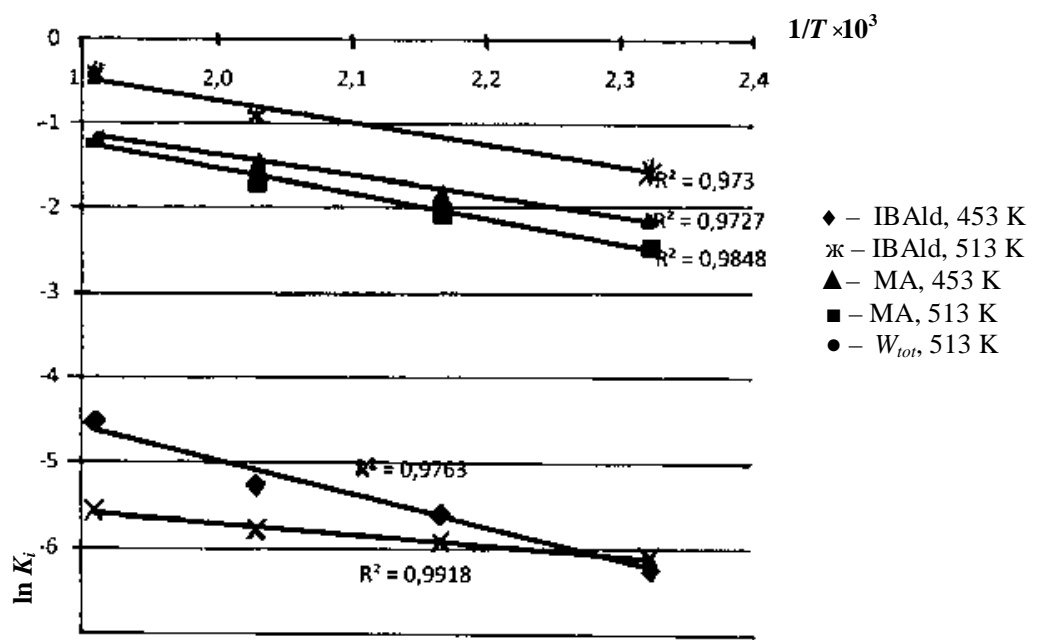

Fig. 3. $\ln \mathrm{K}_{\text {iav }}$ versus $1 / T$ for the reaction of IBA oxidation products obtaining

Using the dependence between $\ln K_{\text {iav }}$ and $1 / T$ (Fig. 3) the activation energies of oxidation products were calculated by the formula $E_{a}=-\operatorname{tg} \alpha \cdot R$ (where $R=8.314-$ gas constant):

$$
\begin{array}{lr}
\text { for IBAld } & E_{a}=24.5 \mathrm{~kJ} / \mathrm{mol} ; \\
\text { for MA } & E_{a}=20.2 \mathrm{~kJ} / \mathrm{mol} \\
\text { for AA } & E_{a}=32.1 \mathrm{~kJ} / \mathrm{mol} \\
\text { for } \mathrm{CO}_{2} & E_{a}=10.7 \mathrm{~kJ} / \mathrm{mol} \\
\text { for IMA conversion } & E_{a}=21.9 \mathrm{~kJ} / \mathrm{mol}
\end{array}
$$

The activation energies values show that the increase in temperature increases the selectivity by acetaldehyde, which is confirmed by the experimental result.

\subsection{Oxidation of Isobutyric Aldehyde to Isobutyric Acid}

This is the second stage of Scheme (1). The experiments were carried out in a flow reactor with stationary catalyst and pulse feed of the reaction mixture $\left(V_{\text {imp }}=12.5 \mathrm{~cm}^{3}, V_{\text {flow }}=0.56 \mathrm{~cm}^{3} / \mathrm{s}, \tau=2.4 \mathrm{~s}\right)$ using different catalysts based on 12-molibdeniumphosphoric heteropolyacid $\left(\mathrm{Cs}_{2} \mathrm{P}_{1} \mathrm{Mo}_{12} \mathrm{~Pb}_{0.2} \mathrm{Cr}_{1} \mathrm{O}_{\mathrm{x}}\right)$. The reaction mixture composition ( $\mathrm{mol} \%$ ) is: IBAld 4.0; water steam 20; air 76. The reaction temperature is $613 \mathrm{~K}$, contact time 2.4 s. IBAld conversion is $70 \%$, selectivity by IBAc $82 \%$, its yield is $63 \%$, acetic acid yield is $63 \%$, and $\mathrm{CO}+\mathrm{CO}_{2}$ yield $14 \%$.

Under the same conditions but using another catalyst $\left(\mathrm{Cs}_{2} \mathrm{P}_{2} \mathrm{Mo}_{12} \mathrm{~Pb}_{0.2} \mathrm{~V}_{1.0} \mathrm{O}_{\mathrm{x}}\right)$ IBAld conversion is $64 \%$ and selectivity by IBAc is $67 \%$. 
The best results are obtained using the catalyst $\mathrm{Mo}_{12} \mathrm{P}_{1} \mathrm{As}_{0.6} \mathrm{Cu}_{0.25} \mathrm{O}_{\mathrm{x}}$ (Table 2).

Table 2

IBAld oxidation to IMAc over $\mathbf{M o}_{12} \mathbf{P}_{1} \mathbf{A s}_{0.6} \mathbf{C u}_{0.25} \mathrm{O}_{x}$

\begin{tabular}{|c|c|c|c|c|}
\hline$T, \mathrm{~K}$ & \multirow{2}{*}{$\begin{array}{c}\text { IBAld } \\
\text { conversion, \% }\end{array}$} & \multicolumn{2}{|c|}{ Selectivity, \% } & IBAc \\
\cline { 3 - 4 } & IBAc & $\mathrm{CO}_{2}$ & yield, \% \\
\hline 463 & 6.0 & 100 & - & 6.0 \\
\hline 493 & 15.0 & 99.0 & 1.0 & 14.8 \\
\hline 523 & 25.0 & 97.0 & 3.0 & 24.2 \\
\hline 553 & 40.0 & 96.0 & 4.0 & 38.4 \\
\hline 583 & 66.0 & 95.0 & 5.0 & 62.8 \\
\hline 613 & 92.0 & 92.0 & 8.0 & 84.6 \\
\hline 643 & 100.0 & 80.0 & 20.0 & 80.0 \\
\hline
\end{tabular}

Maximum selectivity by IBAc (100\%) is obtained at $463 \mathrm{~K}$ but under such conditions IMAld conversion is only $6 \%$. Increase in the temperature increases IMAld conversion and decreases the selectivity by IMAc. Maximum IMAc yield is $84.6 \%$ obtained at $613 \mathrm{~K}$ and contact time of $2.4 \mathrm{~s}$. IMAld complete conversion is achieved at $643 \mathrm{~K}$ but IMAc yield decreases to $80 \%$. Thus the optimal conditions are: $T=613 \mathrm{~K}, \tau=2.4 \mathrm{~s}$,
IBAld concentration in the air $5 \mathrm{~mol} \%$. Under these conditions beside IMAc (yield $84.6 \%$ ) $\mathrm{CO}_{2}$ in the amount of $8 \%$ is also formed.

\subsection{Obtaining of Methylisobutyrate}

The third stage of MMA synthesis is obtaining of methylisobutyrate (MIB). Esterification of IBAc to MIB may be carried out in both gaseous (over KU-2-8- cationic exchanger) and liquid (over toluene sulphate Cat) phases. The results are better for the gaseous phase, MIB yield is above $90 \%$ [3]. In the presence of sulfocationic exchanger the process is carried out at $383-393 \mathrm{~K}$ in the flow reactor with stationary catalyst. To increase the acid conversion the excess of methanol with its recirculation is required. The process schematic diagram is represented in Fig. 4 [3].

Under the laboratory conditions (temperature of $393 \mathrm{~K}$, catalyst $\mathrm{KU}-2-8, \mathrm{CH}_{3} \mathrm{OH}: \mathrm{IBAc}$ ratio 1.5:1.0, methanol recirculation and water azeotropic distillation) the results were the following: IBAc conversion $96.5 \%$, selectivity by MIB $92 \%$, dimethyl ether $8 \%$, reaction time 30 min, and MIB yield $88.8 \%$.

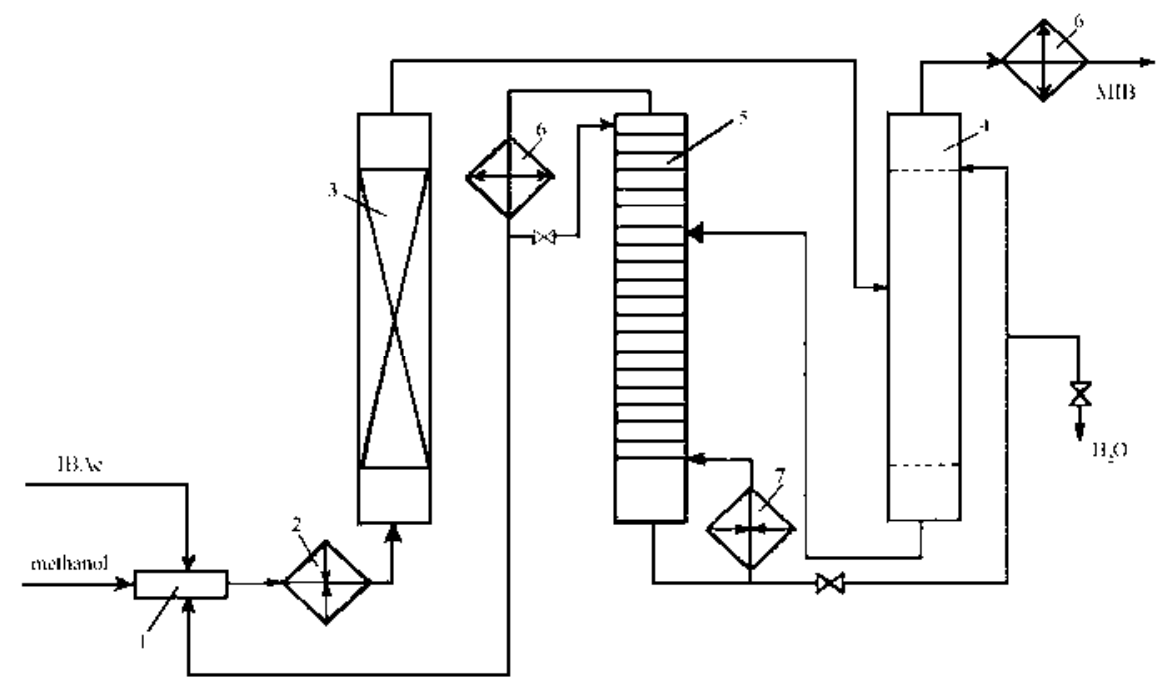

Fig. 4. Schematic diagram of IBAc esterification in the presence of sulfocationic exchanger: mixer (1), evaporator (2), reactor (3), extraction column (4), column for alcohol recuperation (5), condenser (6), and boiler (7)

\subsection{Oxidative Dehydration of Methylisoburate to Methacrylate}

This is the last stage of MMA synthesis. The catalyst based on 12-molibdeniumphosphoric heteropolyacid $\left(\mathrm{H}_{3} \mathrm{PMo}_{12} \mathrm{O}_{40}\right)$ with different promoters which were effective for the reactions of $\mathrm{MA}$ oxidation to MAA [9] and the catalyst $\mathrm{Mo}_{12} \mathrm{P}_{1} \mathrm{As}_{0.6} \mathrm{Cu}_{0.25} \mathrm{O}_{\mathrm{x}}$ [10] (initial one and with $\mathrm{Cr}$ addition) were used for the synthesis. Composition and physico-chemical properties of the investigated catalysts are given in Table 3.
Surface acidity has a great influence on oxidation processes proceeding according to adsorption mechanism. The main reagents are activated over these centres. The surface of the catalysts is heterogeneous. Therefore, the reaction products, as well as substrates hold out on the surface with different forces affecting the reaction selectivity. Irreversible chemosorption of organic substrate is observed over strong acid centres resulting in its decomposition, destructive products formation and complete oxidation. 
Physico-chemical properties of the catalysts for oxidative dehydration of MIB to MA

\begin{tabular}{|c|c|c|c|c|c|c|c|c|}
\hline \multirow[b]{2}{*}{$\begin{array}{l}\text { Catalyst } \\
\text { symbol }\end{array}$} & \multirow[b]{2}{*}{ Atomic composition } & \multirow[b]{2}{*}{$\begin{array}{c}S_{s}, \\
\mathrm{~m}^{2} / \mathrm{g}\end{array}$} & \multicolumn{5}{|c|}{ Surface acidity } & \multirow[b]{2}{*}{$\begin{array}{l}\Sigma N_{c,} \\
10^{-18}\end{array}$} \\
\hline & & & $\begin{array}{c}K, \\
\mathrm{mcmol} / \mathrm{m}^{2}\end{array}$ & $\begin{array}{c}T_{m \mathrm{I}}, \\
\mathrm{K}\end{array}$ & $\begin{array}{c}T_{m \mathrm{II}}, \\
\mathrm{K}\end{array}$ & $\begin{array}{l}E_{1}( \pm 5), \\
\mathrm{kJ} / \mathrm{mol}\end{array}$ & $\begin{array}{l}E_{\mathrm{II}}( \pm 5), \\
\mathrm{kJ} / \mathrm{mol}\end{array}$ & \\
\hline $\mathrm{Cat}_{1}$ & $\mathrm{CsP}_{1} \mathrm{Mo}_{12} \mathrm{~Pb}_{0.2} \mathrm{O}_{\mathrm{x}}$ & 3.0 & 5.4 & 450 & 705 & 74.0 & 300.0 & 3.2 \\
\hline $\mathrm{Cat}_{2}$ & $\mathrm{Cat}_{1}+\mathrm{V}_{1.0}$ & 5.0 & 7.2 & 440 & 705 & 62.0 & 226.0 & 4.3 \\
\hline $\mathrm{Cat}_{3}$ & $\mathrm{Cat}_{1}+\mathrm{W}_{1.0}$ & 3.0 & 3.2 & 440 & 650 & 57.0 & 190.0 & 1.9 \\
\hline $\mathrm{Cat}_{4}$ & $\mathrm{Cat}_{1}+\mathrm{Cr}_{1.0}$ & 8.0 & 7.3 & 403 & 640 & 55.0 & 130.0 & 4.4 \\
\hline $\mathrm{Cat}_{5}$ & $\mathrm{Cat}_{1}+\mathrm{V}_{1.0}+\mathrm{Sn}_{1.0}$ & 6.0 & 7.2 & 423 & 683 & 53.0 & 95.0 & 4.3 \\
\hline $\mathrm{Cat}_{6}$ & $\mathrm{Mo}_{12} \mathrm{P}_{1} \mathrm{As}_{0.6} \mathrm{Cu}_{0.25} \mathrm{O}_{\mathrm{x}}$ & 5.3 & 6.3 & 393 & 653 & 33.0 & 52.0 & 3.8 \\
\hline $\mathrm{Cat}_{7}$ & $\mathrm{Mo}_{12} \mathrm{P}_{1} \mathrm{As}_{0.6} \mathrm{Cu}_{0.25} \mathrm{O}_{\mathrm{x}}+\mathrm{Cr}_{1.0}$ & 4.9 & 6.9 & 383 & 673 & 27.0 & 75.0 & 4.2 \\
\hline $\mathrm{Cat}_{8}$ & $\mathrm{Mo}_{12} \mathrm{P}_{1.2} \mathrm{Sb}_{0.5} \mathrm{~W}_{0.6} \mathrm{~K}_{0.7} \mathrm{O}_{\mathrm{x}}$ & 5.2 & 4.5 & 383 & 663 & 29.0 & 58.0 & 2.7 \\
\hline
\end{tabular}

Notes: $K$ - surface acidity, determined by $\mathrm{NH}_{3}$ chemosorption using pulse chromatographic method at $T=343 \mathrm{~K} ; T_{\mathrm{mI}}$ and $T_{\mathrm{mII}}$ - temperature of thermal desorption maxima at Cat programmed heating; $E_{\mathrm{I}}$ and $E_{\mathrm{II}}( \pm 5)-$ heats of $\mathrm{NH}_{3}$ thermal desorption from Cat surface determined by thermal sorption rate at programmed increase of $T(0.27 \mathrm{~K} / \mathrm{s})$ using the procedure described in [8]; $\Sigma N_{c}-$ amount of acid centres calculated by the amount of chemosorbed $\mathrm{NH}_{3}$ at one-centered chemosorption; $S_{s}$ - Cat specific surface determined by argon thermal desorption [7].

Table 4

Oxidative dehydration of MIB to MMA using mixed oxide catalysts

\begin{tabular}{|c|c|c|c|c|c|c|c|}
\hline \multirow[b]{2}{*}{$\begin{array}{l}\text { Catalyst } \\
\text { symbol }\end{array}$} & \multirow[b]{2}{*}{$T, \mathrm{~K}$} & \multirow{2}{*}{$\begin{array}{c}\text { MIB } \\
\text { conversion, } \\
\%\end{array}$} & \multicolumn{4}{|c|}{ Selectivity, \% } & \multirow[b]{2}{*}{$\begin{array}{c}\text { MMA } \\
\text { yield, \% }\end{array}$} \\
\hline & & & $\mathrm{OA}$ & Acetone & MMA & $\mathrm{CO}+\mathrm{CO}_{2}$ & \\
\hline \multirow{3}{*}{$\mathrm{Cat}_{1}$} & 553 & 41.9 & 9.3 & 11.3 & 70.8 & 8.6 & 29.7 \\
\hline & 563 & 72.1 & 21.4 & 18.0 & 46.9 & 13.5 & 33.7 \\
\hline & 593 & 100.0 & 33.0 & 20.3 & 23.0 & 23.7 & 23.0 \\
\hline \multirow{3}{*}{$\mathrm{Cat}_{2}$} & 533 & 30.6 & 4.0 & 17.5 & 77.0 & 1.5 & 23.8 \\
\hline & 573 & 58.8 & 5.2 & 13.8 & 76.8 & 4.2 & 45.1 \\
\hline & 603 & 82.1 & 7.3 & 10.5 & 76.0 & 6.2 & 62.4 \\
\hline \multirow{3}{*}{$\mathrm{Cat}_{3}$} & 533 & 20.0 & 15.0 & 15.0 & 68.0 & 2.0 & 13.6 \\
\hline & 563 & 75.8 & 18.8 & 10.9 & 61.0 & 9.3 & 46.2 \\
\hline & 573 & 95.3 & 34.0 & 12.8 & 36.4 & 16.8 & 34.7 \\
\hline \multirow{3}{*}{$\mathrm{Cat}_{4}$} & 513 & 80.0 & 0.8 & 8.3 & 88.4 & 2.5 & 70.7 \\
\hline & 523 & 98.0 & 1.0 & 9.1 & 85.4 & 4.5 & 83.7 \\
\hline & 533 & 100.0 & 1.9 & 9.9 & 79.5 & 8.7 & 79.5 \\
\hline \multirow{3}{*}{$\mathrm{Cat}_{5}$} & 533 & 66.0 & 0.9 & 12.2 & 86.3 & 0.6 & 56.8 \\
\hline & 553 & 91.0 & 0.9 & 11.4 & 87.0 & 0.7 & 79.2 \\
\hline & 573 & 96.0 & 1.8 & 11.7 & 85.0 & 1.5 & 81.6 \\
\hline \multirow{4}{*}{$\mathrm{Cat}_{6}$} & 493 & 60.0 & - & 8.5 & 90.0 & 1.5 & 54.0 \\
\hline & 513 & 74.0 & - & 7.3 & 90.0 & 2.7 & 66.6 \\
\hline & 523 & 100.0 & - & 6.2 & 90.0 & 3.8 & 90.0 \\
\hline & 533 & 100.0 & - & 8.5 & 86.0 & 5.5 & 86.0 \\
\hline \multirow{3}{*}{$\mathrm{Cat}_{7}$} & 463 & 63.0 & - & 4.0 & 94.0 & 2.0 & 59.2 \\
\hline & 473 & 83.0 & - & 5.1 & 92.1 & 2.8 & 76.4 \\
\hline & 483 & 100.0 & - & 6.3 & 90.0 & 3.7 & 90.0 \\
\hline \multirow{3}{*}{$\mathrm{Cat}_{8}$} & 483 & 70.0 & 0.4 & 3.0 & 96.0 & 0.6 & 67.2 \\
\hline & 503 & 90.0 & 0.4 & 3.0 & 96.0 & 0.6 & 86.4 \\
\hline & 513 & 100.0 & 0.6 & 3.6 & 95.0 & 0.8 & 95.0 \\
\hline
\end{tabular}

Notes: $5 \mathrm{~mol} \%$ of MIB in the air, $V_{\text {imp }}=9.1 \mathrm{~cm}^{3}, V_{\text {flow }}=0.56 \mathrm{~cm}^{3} / \mathrm{s}, \tau=2.4 \mathrm{~s}$ 
The analysis of surface acidity of investigated catalysts (Table 3 ) show the total acidity decrease in the following order:

$\mathrm{Cat}_{4}>\mathrm{Cat}_{2}=\mathrm{Cat}_{5}>\mathrm{Cat}_{7}>\mathrm{Cat}_{6}>\mathrm{Cat}_{1}>\mathrm{Cat}_{8}>\mathrm{Cat}_{3}$

The strength of acid centres of the first genus by $T_{m}$ decreases in the row:

$\mathrm{Cat}_{1}>\mathrm{Cat}_{2}=\mathrm{Cat}_{3}>\mathrm{Cat}_{5}>\mathrm{Cat}_{4}>\mathrm{Cat}_{6}>\mathrm{Cat}_{7}=\mathrm{Cat}_{8}$

For the centers of the second genus by $T_{m}$ :

$\mathrm{Cat}_{1}=\mathrm{Cat}_{2}>\mathrm{Cat}_{5}>\mathrm{Cat}_{7}>\mathrm{Cat}_{8}>\mathrm{Cat}_{6}>\mathrm{Cat}_{3}>\mathrm{Cat}_{4}$

By the amount of active acid centers:

$\mathrm{Cat}_{2}=\mathrm{Cat}_{5}>\mathrm{Cat}_{4}=\mathrm{Cat}_{6}>\mathrm{Cat}_{7}>\mathrm{Cat}_{1}>\mathrm{Cat}_{8}>\mathrm{Cat}_{3}$

By $E_{1}$ :

$\mathrm{Cat}_{1}>\mathrm{Cat}_{2}>\mathrm{Cat}_{3}>\mathrm{Cat}_{4}>\mathrm{Cat}_{5}>\mathrm{Cat}_{6}>\mathrm{Cat}_{8}>\mathrm{Cat}_{7}$

By $E_{\mathrm{II}}$ :

$\mathrm{Cat}_{1}>\mathrm{Cat}_{2}>\mathrm{Cat}_{3}>\mathrm{Cat}_{4}>\mathrm{Cat}_{5}>\mathrm{Cat}_{7}>\mathrm{Cat}_{8}>\mathrm{Cat}_{6}$

Thus, the obtained rows for the centres of I and II genus are practically identical by activation energy of $\mathrm{NH}_{3}$ desorption. The maximum strength of acid centres by $T_{m}$, $E_{\mathrm{I}}$ and $E_{2}$ has the Cat ${ }_{1}$, whose selectivity by MMA is the least (Table 4). Its surface strongly holds both MIB and products of its conversion followed by their afteroxidation to $\mathrm{CO}-\mathrm{CO}_{2}$.

Taking into consideration MIB conversion degree at $553 \mathrm{~K}$, for $\mathrm{Cat}_{1}-\mathrm{Cat}_{5}$ based on $\mathrm{Cat}_{1}$ and different promoters the following row is observed: $\mathrm{Cat}_{4}>\mathrm{Cat}_{5}>$ $\mathrm{Cat}_{1}>\mathrm{Cat}_{2}>\mathrm{Cat}_{3}$. The row coincides with the row of total acidity (Table 3 ). The catalysts $\mathrm{Cat}_{6}-\mathrm{Cat}_{8}$, containing As $\left(\mathrm{Cat}_{6}\right.$ and $\left.\mathrm{Cat}_{7}\right)$ and $\mathrm{Sb}, \mathrm{W}, \mathrm{K}\left(\mathrm{Cat}_{8}\right)$ differ from $\mathrm{Cat}_{1}-$ $\mathrm{Cat}_{5}$ by their composition, thereby it is incorrect to compare their parameters of surface acidity with those of $\mathrm{Cat}_{1}-\mathrm{Cat}_{5}$. Concerning the amount of acid centres for $\mathrm{Cat}_{1}-\mathrm{Cat}_{5}$, they are situated in the row: $\mathrm{Cat}_{4}>\mathrm{Cat}_{5}=$ $=\mathrm{Cat}_{2}>\mathrm{Cat}_{1}>\mathrm{Cat}_{3}$ which also coincides with their activity (Table 3 ).

IBAc yield at $\mathrm{Cat}_{8}$ is higher by $5 \%$ compared with that at $\mathrm{Cat}_{7}$ but the temperature at $\mathrm{Cat}_{8}$ is also higher (by $30 \mathrm{~K})$. Under experimental conditions $\mathrm{Cat}_{8}$ has the highest selectivity by MMA among all catalysts.

Thus, surface acidity of the catalyst plays a significant role in heterogeneous catalysis. The increase of surface acidity increases Cat activity as a result of existing chemical bonds weakening at its activation and formation of transitional activated complex.

For the first time the connection between Cat surface acidity and Cat activity in the reaction of methanol oxidation was mentioned by N.Pernikone and co-workers [11]. G. Boreskov [12] noted that heterogeneous catalysts activity correlates with the strength of acid centres for acid-base reactions.

The connection between Cat surface acidity and Cat activity is observed in many works. Surface acid centres participate in activation of substrate molecules forming transition activated complex between substrate and surface acid centre. At the same time there are different acid centres on the catalyst surface which adsorb reagents with varied strength. Over strong acid centres an irreversible chemosorption may occur, with the formation of destruction products and complete oxidation compounds. To block such centres a small amount of alkali or earth-alkali elements is introduced into the Cat. One can see from Table 3 that $\mathrm{Cat}_{7}$ has the least temperature at which $80 \%$ and $100 \%$ conversion of MIB is achieved. But MIB selectivity by MMA is lower by $5 \%$ than that for $\mathrm{Cat}_{8}$. Obviously the chrome oxide introduced into $\mathrm{Cat}_{6}$, increases surface acidity and activity of the catalyst. Comparison of the temperatures at which MIB conversion is $80 \%$ and selectivity by MMA is high shows that the most active catalysts are $\mathrm{Cat}_{7}$ and $\mathrm{Cat}_{8}$. Using $\mathrm{Cat}_{7}$ the complete MIB conversion is $100 \%$ at $483 \mathrm{~K}$ and using $\mathrm{Cat}_{8}$ (the most selective one) - at $513 \mathrm{~K}$ (Table 5).

Table 5

\section{Temperature and selectivity by MMA at MIB conversion $80 \%$ (see experimental conditions in Table3)}

\begin{tabular}{|c|c|c|c|}
\hline $\begin{array}{c}\text { Catalyst } \\
\text { symbol }\end{array}$ & $T, \mathrm{~K}$ & $\mathrm{~S}_{\mathrm{MMA}}, \%$ & $\begin{array}{l}\mathrm{Y}_{\mathrm{MMA}}{ }^{*}, \% \\
\text { at } T_{\text {opt }}(\mathrm{K})\end{array}$ \\
\hline $\mathrm{Cat}_{1}$ & 580 & 38.0 & $33.7(563)$ \\
\hline $\mathrm{Cat}_{2}$ & 575 & 70.0 & $62.4(603)$ \\
\hline $\mathrm{Cat}_{3}$ & 568 & 55.0 & $46.2(563)$ \\
\hline $\mathrm{Cat}_{4}$ & 513 & 88.0 & $83.7(523)$ \\
\hline $\mathrm{Cat}_{5}$ & 543 & 86.0 & $81.6(573)$ \\
\hline $\mathrm{Cat}_{6}$ & 518 & 90.0 & $90.0(523)$ \\
\hline $\mathrm{Cat}_{7}$ & 468 & 93.0 & $90.0(483)$ \\
\hline $\mathrm{Cat}_{8}$ & 493 & 95.0 & $95.0(513)$ \\
\hline
\end{tabular}

* Maximum yield at temperature optimal for Cat

Based on the temperature at which $80 \%$ conversion of MIB is achieved, the catalysts form the row:

$\mathrm{Cat}_{1}>\mathrm{Cat}_{2}>\mathrm{Cat}_{3}>\mathrm{Cat}_{5}>\mathrm{Cat}_{6}>\mathrm{Cat}_{4}>\mathrm{Cat}_{8}>\mathrm{Cat}_{7}$.

The yield achieved using $\mathrm{Cat}_{8}(95 \%)$ at $513 \mathrm{~K}$ is higher than that using $\mathrm{Cat}_{7}$ (90\%). At lower temperature (483 K) MIB conversion is $100 \%$ for the both catalysts.

Obviously the process selectivity may be determined by thermodynamic characteristics of acidity, i.e. strength of adsorbate holding on the surface and heat of activated thermal desorption of oxidation products. At MIB conversion of $80 \%$ the selectivity by MMA for the catalysts decreases in the row: $\mathrm{Cat}_{4}>\mathrm{Cat}_{5}>\mathrm{Cat}_{2}>\mathrm{Cat}_{3}>$ $\mathrm{Cat}_{1}$. By $E_{\mathrm{I}}$ the following row is obtained: $\mathrm{Cat}_{1}>\mathrm{Cat}_{2}>$ $\mathrm{Cat}_{3}>\mathrm{Cat}_{4}>\mathrm{Cat}_{5} ; E_{\mathrm{II}}: \mathrm{Cat}_{1}>\mathrm{Cat}_{2}>\mathrm{Cat}_{3}>\mathrm{Cat}_{4}>\mathrm{Cat}_{5}$. Selectivity by $T_{m \mathrm{I}}: \mathrm{Cat}_{1}>\mathrm{Cat}_{2}=\mathrm{Cat}_{3}>\mathrm{Cat}_{5}>\mathrm{Cat}_{4} ; T_{m \mathrm{II}}$ : $\mathrm{Cat}_{1}>\mathrm{Cat}_{2}>\mathrm{Cat}_{3}>\mathrm{Cat}_{4}>\mathrm{Cat}_{5}$.

The comparison of selectivity row with acidity strength $\left(\mathrm{NH}_{3}\right.$ adsorption strength) shows that the greater the acidity strength, the less the selectivity of the Cat. 


\section{Conclusions}

1. Cat ${ }_{8}$ is the best of all investigated catalysts. The maximum MMA yield (95\%) with complete MIB conversion is achieved over this Cat at $513 \mathrm{~K}$, contact time $2.4 \mathrm{~s}$ and MIB concentration in the air $5 \mathrm{~mol} \%$.

2. Ether oxidative dehydration gives better results compared with IBAc dehydration. MMA yield calculated for supplied IBA is: $97.3 \%$ (1 stage), $84.6 \%$ (2 stage), $90 \%$ ( 3 stage), and $95 \%$ (4 stage). The total MMA yield is $70.4 \%$.

3. Taking into account that acid is an initial material for IBAc dehydration and in our case IBA gives the additional stages 1 and 2 with high yields (97.3 and $84.6 \%$ ) the investigated scheme of IBA use for MMA synthesis may be applied in the industry.

\section{References}

[1] Dvonchova E.: PhD thesis, Lviv, Ukraine 1988.

[2] Khan R.: PhD thesis, Lviv, Ukraine 1997.

[3] Lebedev N.: Khimiya i Technologiya Osnovnogo Organicheskogo i Neftekhimicheskogo Sinteza. Khimiya, Moskwa 1988.

[4] Gelevan F.: PhD thesis, Lviv, Ukraine 1987.

[5] Zhyznevskiy V.: D.Sc. thesis, Lviv, Ukraine 1982.
[6] Shchukin V., Veniaminov S. and Boreskov G.: Kinetika i Kataliz, 1970, 5, 1236.

[7] Reiter V. (Ed.): Problemy Teorii i Praktiki Issledovanij v Oblasti Kataliza. Naukova dumka, Kyiv 1973.

[8] Kharlamov V., Bogomolov V., Mirzabbekova N. et al:: Zh. Phys. Khim., 1976, 2, 343.

[9] Zhyznevskiy V., Shypailo V., Grymalyuk B. and Bazhan L.: Ukr. Khim. Zh., 1996, 11, 22.

[10] Bazhan L., Zhyznevskiy V. and Khan R.: Visnyk Lviv Polytechnic University, 1977, 316, 111.

[11] Pernikone N., Liberti J. and Ersini L.: Mat. Int.Conf. "Osnovy Predvideniya Kataliticheskogo Deistvia”, Moskwa 1970, 1, 244.

[12] Boreskov G.: Kinetika i kataliz, 1970, 1, 5.

\section{ВИКОРИСТАННЯ ІЗОБУТИЛОВОГО СПИРТУ ДЛЯ СИНТЕЗУ МЕТАКРИЛАТІВ}

Анотація. Досліджено синтез метилметакрилатів окиснювальним перетворенням ізобутилового спирту за різними схемами. Встановлена можливість використання його як вихідної альтернативної сировини ізобутилену та трет.бутиловому спирту. При одержанні метилметакрилатів за схемою: ізобутиловий спирт $\rightarrow$ метакрилонітрил $\rightarrow$ метилметакрилат одержано продукт, сумарний вихід якого на поданий спирт дорівнюе $64,8 \%$, a 3 рециркуляцією непрореагованого метакролеїну - 81,9 \%. Цю схему можна рекомендувати для впровадження в промисловість.

Ключові слова: окиснення, окиснювальний амоноліз, каталізатор, метакрилонітрил, метилметакрилат. 